\title{
Pemberdayaan Masyarakat Dusun Pengantap Kabupaten Lombok Barat Melalui Program "Bakat Militan Emas"
}

\author{
Fahmi Handika ${ }^{1}$, M. Vergiawan Saputra ${ }^{2}$, Sujud Alfanza Jihad ${ }^{2}$, Nurul Rizkiaeni Ganevia ${ }^{3}$, \\ Mega Safana ${ }^{4}$ \\ ${ }^{1}$ Fakultas Matematika dan Ilmu Pengetahuan Alam, Universitas Mataram, Mataram, Indonesia; \\ ${ }^{2}$ Fakultas Teknik, Universitas Mataram, Mataram, Indonesia; \\ ${ }^{3}$ Fakultas Ekonomi \& Bisnis, Universitas Mataram, Mataram, Indonesia; \\ ${ }^{4}$ Fakultas Keguruan \& Ilmu Pendidikan, Universitas Mataram, Mataram, Indonesia;
}

DOI: https://doi.org/10.29303/jpmsi.v2i1.32

Citation: Handika, F., Saputra, M., V., Jihad, S., A., Ganevia, N., R., Safana, M. 2020. Pemberdayaan Masyarakat Dusun Pengantap Kabupaten Lombok Barat Melalui Program "Bakat Militan Emas". Jurnal Pengabdian Masyarakat Sains Indonesia (JPMSI). 2(1): 92-97.

Article history

Received: Mei $14^{\text {th }} 2020$

Revised: Mei $18^{\text {th }} 2020$

Accepted: Mei $28^{\text {th }} 2020$

*Corresponding Author: Fahmi Handika, Universitas Mataram, Mataram, Indonesia.

Email:

fahmihandika4@gmail.com

\begin{abstract}
Abstrak: Dusun Pengantap merupakan salah satu dari 10 wilayah minapolitan rumput laut di NTB. Masyarakat Dusun Pengantap sebagian besar bermatapencaharian sebagai petani rumput laut. Disisi lain, bencana gempa bumi yang melanda pulau Lombok beberapa waktu lalu berdampak terhadap kapasitas produksi rumput laut pada dusun tersebut. Hal ini diperparah dengan kondisi masyarakat yang memiliki tingkat pendidikan yang rendah dan pasifnya kelompok rumput laut di Dusun Pengantap. Tujuan Kegiatan Pengabdian Kepada Masyarakat adalah untuk menghidupkan kembali kelompok pengolahan rumput laut di Dusun Pengantap serta meningkatkan skill pengolahan rumput laut agar dapat memiliki value added. Kegiatan Pengabdian kepada masyarakat ini dilaksanakan dengan sebuah program yang diberi nama BAKAT MILITAN EMAS (Bangun Masyarakat Minapolitan Rumput Laut Eucheuma Spinosum). Kegiatan pengabdian kepada masyarakat ini dilaksanakan selama 4 bulan agar dapat memberikan pendampingan intensif. Kegiatan pengabdian kepada masyarakat terdiri atas kegiatan sosialisasi, pretest dan posttest dengan kuisioner, pelatihan dan pendampingan serta pemasaran. Kegiatan pengabdian kepada masyarakat diikuti oleh 10 orang peserta dari Dusun Pengantap Kecamatan Sekotong Kabupaten Lombok Barat. Hasil pelaksanaan kegiatan pengabdian kepada masyarakat berhasil diproduksikan sebuah produk Dodol Rumput Laut Tematik (DORATA) dengan berbagai varian bentuk, warna dan rasa.
\end{abstract}

Kata Kunci: Dusun Pengantap, Rumput Laut, Eucheuma Spinosum, Bakat Militan Emas, Dorata.

\section{Pendahuluan}

Nusa Tenggara Barat terdiri atas dua pulau besar yakni pulau Lombok dan Sumbawa. Kekayaan sumber daya alam yang ada pada dua pulau tersebut sangat berlimpah, baik pada sektor pertanian, perkebunan, perikanan dan kelautan. Sejak tahun 2009 pemerintah provinsi NTB telah gencar melaksanakan program PIJAR. Adapun PIJAR merupakan program pengembangan tiga komoditas unggulan NTB yaitu sapi, jagung dan rumput laut.

Rumput laut memiliki manfaat yang banyak bagi manusia._Anggadiredja (1993) menyatakan bahwa rumput laut dapat dijadikan sumber gizi karena mengandung karbohidrat, protein, sedikit lemak dan abu yang sebagian besar merupakan senyawa garam seperti natrium dan kalium, di samping itu juga sebagai sumber vitamin seperti vitamin A, B1, B6, B12 dan vitamin C serta mineral seperti K, Ca, P, Na, Fe dan I. Kadir (2000) menyebutkan bahwa kandungan gizi rumput laut 
Handika et al, Jurnal Pengabdian Masyarakat Sains Indonesia 2020, 2 (1): 92-97. DOI : https://doi.org/10.29303/ipmsi.v2i1.32

per 25 gram bahan adalah sebagai berikut kadar air $30,03 \%$; karbohidrat 11,29\%; protein 1,96\%; lemak 0,13\%; serat kasar 3,9\%; Fe 548,63 ppm; $\mathrm{Mg}$ 2104,90 ppm; Ca 8510,18 ppm dan I 2,83 ppm. Andriani (2007) bahkan menunjukkanbahwa karaginan yang dimiliki oleh rumput laut Eucheuma sp. mampu berperanan sebagai stabilisator, bahan pengental dan pengemulsi. Angka dan Suhartono (2000) juga menyebutkan secara spesifik bahwa karaginan dari Eucheuma sp. dapat digunakan sebagai bahan makanan,pembentukan gel dalam sirup, selai, saus, makanan bayi, produk susu.

NTB menjadi salah satu provinsi yang banyak menghasilkan rumput laut di Indonesia. Terdapat 10 sentra minapolitan rumput laut di NTB, baik yang berada di pulau Lombok maupun Sumbawa. Salah satu sentra minapolitan tersebut adalah Dusun Pengantap yang berada di Desa Buwun Mas, Kecamatan Sekotong, Kabupaten Lombok Barat. Dusun ini memiliki potensi pengembangan rumput laut hingga 600 hektar.

Sumber penghidupan utama masyarakat Buwun Mas umumnya sangat bergantung pada sumber daya alam khususnya pertanian. Menurut data profil desa yang tersedia di desa bahwa yang bermata pencaharian sebagai petani 3.856 orang dan buruh tani mencapai 1.187 orang sementara yang bermata pencaharian sebagai nelayan hanya 264 orang saja. Lahan sawah seluas 1.920 ha dengan sistem pengairan sawah tadah hujan seluas 1.805 ha dan sawah irigasi 115 ha. Sedangkan tanah kering berupa tegal/ladang seluas 2.536 ha dan perkebunan rakyat seluas 65 ha serta tanah rawa seluas 75 ha. Terdapat kelompok budidaya rumput laut di dusun Pengantap sebanyak 60 kelompok (Anonim, 2015).

Kondisi masyarakat Desa Buwun Mas pula menjadi suatu perhatian khusus, sebab Dusun Pengantap sebagai penyumbang kuantitas masyarakat miskin. Jumlah keluarga miskin yakni sebanyak 1.992 KK (85\%) dari 2.348 KK di Desa Buwun Mas. Jumlah penduduk miskin sebanyak 8.122 jiwa atau $87 \%$ orang dari 9.284 orang total jumlah penduduk di Desa Buwun Mas (Anonim, 2010) .

Masyarakat Dusun Pengantap sebagian besar bermatapencaharian sebagai petani rumput laut. Setiap keluarga di memiliki usaha tani rumput laut. Jenis rumput laut yang ditanam di kawasan ini merupakan jenis Eucheuma Spinosum
e-ISSN : 2715-2537

p-ISSN : 2715-2545

yang dimanfaatkan dalam pengolahan pangan. Rumput laut dijual dalam keadaan kering tanpa ada pengolahan lebih lanjut.

Berdasarkan hasil wawancara dan diskusi dengan ketua kelompok rumput laut pada tanggal 5 Desember 2018, panen yang dihasilkan dalam satu bulan dapat mencapai angka 15 ton rumput laut basah. Namun sejak terjadinya bencana gempa yang menimpa Lombok pada 5 Agustus 2018 silam, jumlah produksi rumput laut berkurang drastis. Petani hanya mampu menghasilkan 1-2 ton rumput laut basah dalam satu bulan.

Penurunan jumlah produksi pasca gempa, tentunya memberikan dampak bagi penurunan perekonomian di Dusun Pengantap. Hal ini diperparah dengan kondisi masyarakat yang memiliki tingkat pendidikan kurang dan pasifnya kelompok rumput laut disana. Bahkan keterampilan yang dimiliki masyarakat untuk mengolah rumput laut pun masih sangat minim. Sehingga produk yang ditawarkan masih berupa bahan mentah. Padahal Dusun Pengantap memiliki potensi masyarakat yang cukup besar untuk memaksimalkan potensi rumput laut yang ada.

Berdasarkan permasalahan yang telah dipaparkan, sebuah kegiatan pengabdian kepada masyarakat layak untuk dilakukan di Dusun Pengantap tersebut. Kegiatan pengabdian kepada masyarakat ini dilaksanakan melalui sebuah program yang diberi nama Bakat Militan Emas (Bangun Masyarakat Minapolitan Rumput Laut (Eucheuma Spinosum)). Program ini diharapkan mampu meningkatkan produktivitas dan perekonomian masyarakat Dusun Pengantap melalui produk pengembangan rumput laut.

\section{Metode}

Metode kegiatan pengabdian kepada masyarakat melalui program Bakat Militan Emas (BME) dilaksanakan dengan tahapan sebagai berikut.

1. Tahap Persiapan

1.1 Rapat anggota, bertujuan untuk menyatukan persepsi anggota dengan ketua. Rapat anggota membahas hal umum tentang keberlanjutan program, pembagian tugas setiap anggota, penyelesaian masalah bersama dan langkah strategis yang akan diambil. 
Handika et al, Jurnal Pengabdian Masyarakat Sains Indonesia 2020, 2 (1): 92-97. DOI : https://doi.org/10.29303/ipmsi.v2i1.32

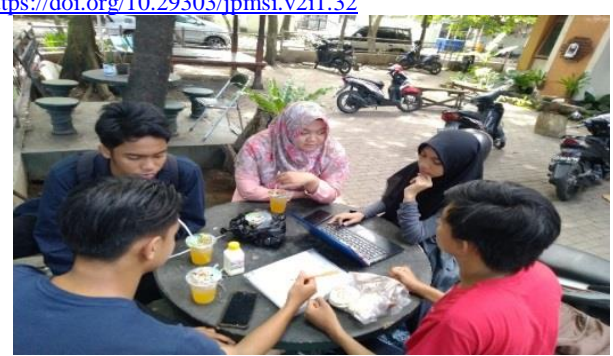

Gambar 1. Rapat anggota

1.2 Rapat koordinasi, bertujuan untuk menyatukan persepsi tim PKM dengan pembimbing. Rapat koordinasi diperlukan untuk mendapat masukan pembimbing serta membahas langkah strategis yang akan diambil dalam hal pelaksanaan dan keberlanjutan.

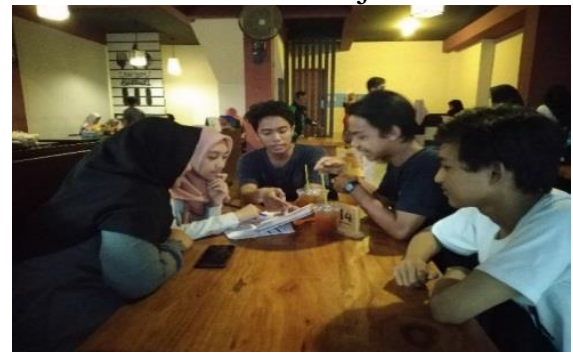

Gambar 2. Rapat koordinasi

1.3 Survei lokasi, bertujuan untuk melihat latar belakang pendidikan, kondisi masyarakat, permasalahan sosial, masyarakat dan wilayah lebih detail. Latar belakang pendidikan dan matapencaharian berpengaruh terhadap sasaran program. Kondisi masyarakat akan mempengaruhi cara penyampaian dan pelaksanaan program BAKAT MILITAN EMAS. Survei wilayah berguna untuk penentuan lokasi.

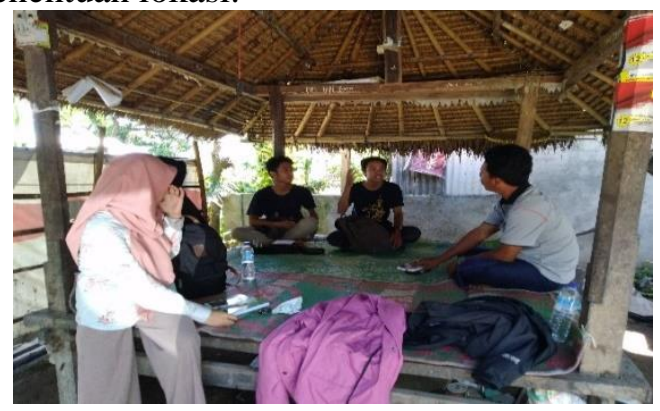

Gambar 3. Survey lokasi

1.4 Melakukan perijinan, bertujuan menjalin hubungan yang terlindung secara hukum antara tim PKM dengan objek sasaran program. Perijinan dilakukan di dusun Pengantap desa Buwun Mas kecamatan
e-ISSN : 2715-2537

p-ISSN : 2715-2545

Sekotong. Perijinan terdiri dari perijinan pelaksanaan dan komponen pendukung pelaksanaan terdiri dari pinjam tempat, pinjam peralatan dan perlengkapan.

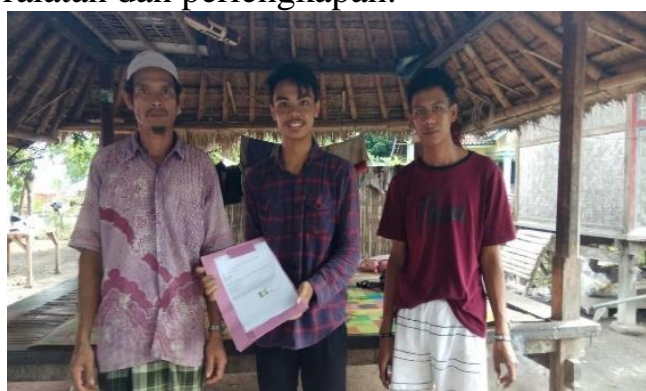

Gambar 4. Perijinan

1.5 Melakukan kerjasama, bertujuan untuk memperkuat teknik pelatihan dan mencari dukungan dengan instansi atau pihak lain. Perundingan jadwal pelatihan atau pelaksanaan program BAKAT MILITAN EMAS.

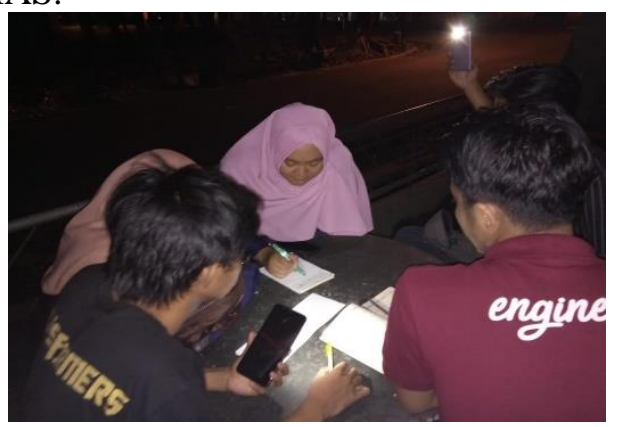

Gambar 5. Perundingan jadwal pelatihan

\section{Tahap Pelaksanaan Kegiatan}

2.1 Ceramah, pemberian materi secara lisan dan tatap muka yang dilakukan saat pertama kali melakukan pelatihan dan pelaksanaan.

2.2 Praktik, pemenuhan teori yang dijelaskan dalam bentuk materi secara praktik agar memenuhi kemampuan mengolah rumput laut menjadi DORATA pada program Bakat Militan Emas.

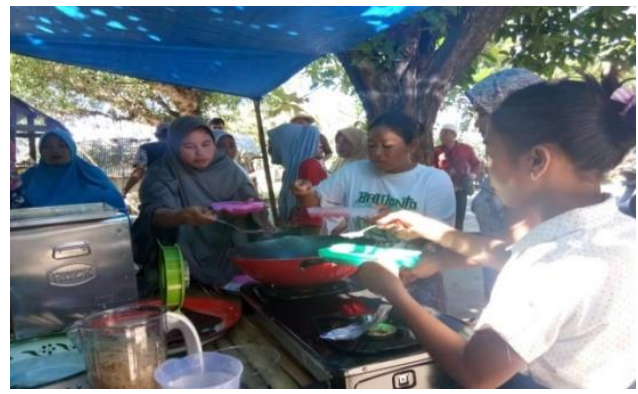

Gambar 6. Praktik pembuatan 
Handika et al, Jurnal Pengabdian Masyarakat Sains Indonesia 2020, 2 (1): 92-97. DOI : https://doi.org/10.29303/ipmsi.v2i1.32

2.3 Pemantauan, tim PKM Pengabdian Kepada Masyarakat dan dosen pembimbing program Bakat Militan Emas melakukan pemantauan dengan tujuan terwujudnya kemandirian bagi masyarakat dusun Pengantap dalam program BAKAT MILITAN EMAS.

\section{Tahap Pendampingan Iptek}

Pembentukan karakter kewirausahaan kepada masyarakat dusun Pengantap seperti BAKAT MILITAN EMAS tidak terlepas dari peranan ilmu pengetahuan dan teknologi (IPTEK). Sehingga, program BAKAT MILITAN EMAS perlu adanya pendampingan ilmu pengetahuan dan teknologi (IPTEK). Maka dari itu, program BAKAT MILITAN EMAS menerapkan pendidikan karakter kewirausahaan melalui pendidikan kesehatan terhadap bahan pangan yang diproduksi sendiri. Bentuk dari pendidikan kesehatan pangan program BAKAT MILITAN EMAS adalah adanya penyampaian khasiat rumput laut melalui booklet yang diberikan tim PKM Pengabdian Kepada Masyarakat BAKAT MILITAN EMAS.

Pendampingan IPTEK lainnya yang dilakukan tim PKM adalah sebagai berikut.

a) Pembentukan struktur kelembagaan dalam kelompok BAKAT MILITAN EMAS, bertujuan untuk menjaga keberlanjutan program BAKAT MILITAN EMAS. Kelompok ini ditempatkan di rumah ketua kelompok.

b) Perekrutan karyawan, bertujuan untuk menjaga keberlanjutan program BAKAT MILITAN EMAS.

c) Pengembangan mandiri, pelaku kelompok terlembaga BAKAT MILITAN EMAS diberikan kebebasan menciptakan produk dengan kreasi sendiri demi melanjutkan program.

4. Tahap Pengontrolan dan Evaluasi BAKAT MILITAN EMAS

4.1 Pada tahap pengontrolan, dilakukan pengontrolan secara rutin terhadap berjalannya pelaksanaan program BAKAT MILITAN EMAS, serta pengontrolan terhadap kehadiran masyarakat yang terlibat dalam program BAKAT MILITAN EMAS yakni masyarakat dusun PENGANTAP.
e-ISSN : 2715-2537

p-ISSN : 2715-2545

4.2 Evaluasi kegiatan dilakukan secara bertahap dan berkala. Hasil kegiatan akan diukur dengan indikator keberhasilan yang telah ditentukan sebelumnya sehingga dapat digunakan sebagai titik tolak dalam pengembangan selanjutnya.

\section{Hasil dan Pembahasan}

Hasil dari pelaksanaan kegiatan pengabdian kepada masyarakat ini yakni terdapat target luaran yang meliputi terciptanya suatu produk DORATA sebagai upaya meningkatkan kesejahteraan masyarakat Dusun Pengantap Desa Buwun Mas Sekotong pasca gempa Lombok. Serta, terbentuknya kelompok masyarakat yang terampil dalam pengolahan rumput laut

Kegiatan pengabdian kepada masyarakat ini telah menghasilkan suatu produk, yaitu DORATA. Produk ini diharapkan dapat meningkatkan kesejahteraan masyarakat Dusun Pengantap Desa Buwun Mas pasca gempa Lombok. Program BAKAT MILITAN EMAS yang dilaksanakan di Dusun Pengantap Desa Buwun Mas Kecamatan Sekotong, Kabupaten Lombok Barat dapat dinilai berjalan dengan baik. Langkah pertama dalam program ini adalah observasi daerah sasaran yang bertujuan mengetahui permasalahan dan potensi yang ada di daerah tersebut. Setelah permasalahan dipetakan secara baik dan potensi daerah tersebut benar-benar dapat dimanfaatkan, langkah selanjutnya adalah melakukan perizinan pelaksanaan program kepada pihak yang terkait, dalam hal ini adalah Ketua Kelompok Rumput Laut Dusun Pengantap. Respon dari pihak mitra sangatlah baik dan mendukung diadakanya program yang diusulkan, selain itu diharapkan program tersebut juga dapat dirasakan manfaatnya oleh masyarakat sekitar.

DORATA (Dodol Rumput Laut Tematik), merupakan produk inovasi dodol rumput laut yang memiliki berbagai varian bentuk, rasa dan warna. DORATA diharapkan mampu menjadi produk olahan rumput laut yang dapat meningkatkan penghasilan masyarakat Dusun Pengantap serta menjadi wadah pelatihan peningkatan skill masyarakat Dusun Pengantap. 
Handika et al, Jurnal Pengabdian Masyarakat Sains Indonesia 2020, 2 (1): 92-97. DOI : https://doi.org/10.29303/ipmsi.v2i1.32

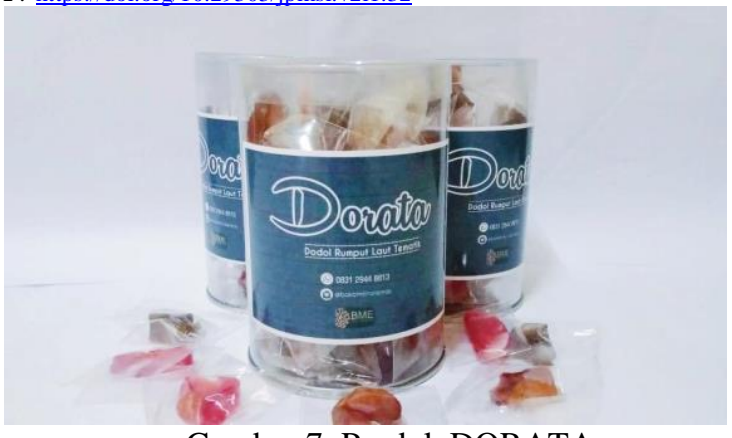

Gambar 7. Produk DORATA

Hasil pelaksanaan kegiatan pengabdian kepada masyarakat yang kedua adalah terbentuknya masyarakat yang terampil dalam mengolah rumput laut menjadi produk olahan rumput laut dengan value added yang bernilai jual tinggi. Demi terbentuknya masyarakat yang terampil dalam mengelola rumput laut maka dilaksanakanlah sosialisasi program BAKAT MILITAN EMAS dan pelatihan pembuatan DORATA. Adapun kegiatan sosialisasi tersebut dilaksanakan pada tanggal 7 April 2019 pukul 09.00- 12.00 Wita yang diikuti oleh 26 warga Dusun Pengantap, Desa Buwun Mas. Kegiatan dimulai dari pembukaan seperti sambutan dari Kepala Dusun, Ketua Kelompok PKM, tilawah, dan doá. Setelah itu diadakannya penyuluhan mengenai rantai nilai rumput laut sebagai edukasi masyarakat serta masyarakat diminta untuk mengisi kuisioner untuk lebih mengenal program yang akan dilaksanakan. Dalam pengenalan program ini sambutan warga sangat baik, hal ini dari respon-respon warga saat sesi Tanya jawab.

Pelatihan Pembuatan DORATA dilakukan setelah diadakanya sosialiasi program BAKAT MILITAN EMAS. Konsepnya pemateri menjelaskan teknik pembuatan DORATA, dimulai dari pengenalan bahan-bahan, tata cara pembuatan dan demo pembuatan DORATA. Pelaksanaan dan pelatihan program BAKAT MILITAN EMAS telah dilakukan sebanyak 3 kali dengan antusian masyarakat Dusun Pengantap yang sangat tinggi dalam menjalankan program BAKAT MILITAN EMAS. Hasil yang diperoleh dari pelatihan dan pelaksanaan tersebut yaitu terciptanya produk DORATA dengan varian rasa strawberry, sirsak dan mangga. Sampai saat ini produk yang dihasilkan masyarakat dusun Pengantap telah dalam tahap pemasaran baik online maupun offline. Produk DORATA pun disambut antusias oleh masyarakat sekitar.

\section{Kesimpulan}

e-ISSN : 2715-2537

p-ISSN : 2715-2545

Kesimpulan dari pelaksanaan kegiatan pengabdian kepada masyarakat ini adalah Masyarakat Dusun Pengantap memiliki antusiasme yang sangat tinggi dalam pelaksaaan program BAKAT MILITAN EMAS. Melalui program BAKAT MILITAN EMAS yang telah dilaksanakan, keterampilan masyarakat Dusun Pengantap dalam mengolah rumput laut menjadi produk olahan rumput laut pun meningkat. Masyarakat Dusun Pengantap telah mampu membuat produk DORATA (Dodol Rumput Laut Tematik), sehingga program BAKAT MILITAN EMAS telah mampu menciptakan produk DORATA dan membentuk masyarakat yang memiliki keterampilan dalam mengolah rumput laut.

\section{Saran}

Kepada masyarakat, perlu terus menambah pengetahuan dalam mengelola rumput laut serta terus berinovasi dalam menciptakan produk olahan rumput laut.

\section{Ucapan Terima Kasih}

Ucapan terimakasih kepada kemenristekdikti yang telah mendukung terlaksananya program BAKAT MILITAN EMAS melalui Program Kreatifitas Mahasiswa Bidang Pengabdian Masyarakat yang telah mendukung secara finansial maupun pembekalan materi. Ucapan terimakasih kepada dosen pembimbing bapak Drs. Jeckson Siahaan, M.Pd yang telah membimbing dalam pengerjaan artikel ilmiah dan membimbing dalam setiap kegiatan pada program BAKAT MILITAN EMAS.

\section{Daftar Pustaka}

Anonim. 2015. "Profil Desa Buwun Mas Tahun 2015" Kecamatan Sekotong, Kabupaten Lombok Barat Nusa Tenggara Barat.

Anonim. 2010. "Dokumen RPJMDesa Buwun Mas Tahun 2010" Kecamatan Sekotong, Kabupaten Lombok Barat Nusa Tenggara Barat.

Andriani D. 2007. Pengolahan Rumput Laut (Eucheuma cottonii) menjadi Tepung 
Handika et al, Jurnal Pengabdian Masyarakat Sains Indonesia 2020, 2 (1): 92-97. DOI : https://doi.org/10.29303/ipmsi.v2i1.32

ATC (Alkali Treated Carrageenophyte) dengan Jenis dan Konsentrasi Larutan Alkali yang berbeda. Jurusan Teknologi Pertanian.

Fakultas

Pertanian dan Kehutanan. Universitas Hasanudin. Makasar.

Anggadiredja. 1993. Teknologi Produk Perikanan dalam Industri Farmasi._Makalah Stadium Generale Teknologi dan Alternatif Produk Perikanan dalam Industri. Bogor.

Angka S.L. dan Suhartono M.T. 2000. Bioteknologi Hasil Laut. Pusat Kajian Sumberdaya Pesisir dan Lautan. IPB.Bogor.

Kadir S. 2000. Studi Kandungan Yodium dan Serat pada Berbagai Konsentrasi Gula dan Air Juice Rumput Laut. Tesis Pasca Sarjana Universitas Airlangga. Surabaya. 